\title{
Evaluating Certified Indonesian EFL Teachers' Performance: A Case Study in a High School in Aceh
}

\author{
Zulfikar \\ zulfikar@stain-madina.ac.id \\ Sekolah Tinggi Agama Islam Negeri Mandailing Natal
}

\begin{abstract}
This study is entitled "Evaluating Certified Indonesian EFL Teachers' Performance: A Case Study in a High School in Aceh". The objective of this study is to identify to what extent Indonesia's teacher certification program affects English as a Foreign Language (EFL) teachers' instructional performance. The data were collected through in-depth interview and observations in a prominent state senior high school in Aceh Besar, Aceh, involving three certificated EFL teachers, fifteen EFL learners and the vice principal of curriculum affairs as participants. The data were subsequently analyzed by thematic analysis with the results distributed into separate themes. The results showed that even though all the teachers were knowledgably well-versed in their ability to devise well-elaborated lesson plans, two of them still exhibited a relatively strict adherence to the whole-class and teacher-centered instructions, with limited use of medias and varied learning sources, causing concern for both EFL learners and the school's vice principal of curriculum affairs.
\end{abstract}

Keywords: Teacher Certification Program, certified EFL teachers, teachers' performance, EFL learners

\section{INTRODUCTION}

The accomplishment of the objectives of education depends on such factors as teachers, students, learning facilities and infrastructure, educational environment, and curriculum. Of these elements, teachers occupy a central position in making educated and intelligent judgements about practice to achieve the intended learning outcome with and for their learners. In Indonesia, the position of teachers as professional educators has been implicitly asserted in Law Number 20 of 2003 concerning the National Education System, Law Number 14 of 2005 concerning teachers and lecturers, Government Regulation Number 19 of 2005 concerning National Education Standards and Government Regulation Number 74 of 2008 concerning teachers, all of which specify that teachers are professional educators tasked mainly to educate, teach, guide, direct, train, assess, and evaluate their pupils through formal education at early childhood, primary and secondary levels.

The laws also stipulate that a professional teacher must possess a minimum academic qualification of a bachelor's or associate's degree and demonstrate their pedagogical, professional, social, and personal competencies. Of the four competencies, pedagogical competence is the one that is directly related to the teaching and learning process since it showcases teachers' ability to manage students' learning which encompasses course planning, implementation and evaluation. Professional competence, on the other hand, is indicated by a teacher's extensive knowledge of the field of study and his or her mastery of diverse teaching methods and techniques. According to the Government Regulation Number 19 of 2005 concerning National Education Standards, a professionally competent teacher has a profound command of scientific, technological and artistic concepts, structures, and methods that are coherent with teaching materials; conceptual connection 
between interrelated subjects; and authentic application of scientific theories. He or she is capable of professionally competing in a global stage while upholding domestic values and culture, and is committed to creating a supportive classroom climate and inspiring their learners to focus on their continued development.

Personality competence is characterized by a teachers' resolute, stable, mature, wise, and dignified disposition, which reflects his or her noble character as role models who constantly evaluate themselves in order to develop his or her performance (Wardoyo, 2015). It denotes teachers' ability to nurture students' personality while attempting to accomplish learning objectives at the same time. This competence is revealed in teachers' conscious and systematic endeavors in promoting a conducive educational atmosphere that can facilitate the development of not only students' intelligence and skill sets but also their mental and spiritual capacities, selfcontrol, character traits, and integrity to the best extent (Hakim, 2015).

As part of a broader community, teachers are also required to possess a skill to communicate and socialize efficaciously with learners and their parents, fellow educators, education staff, and general public. This so-called social competence is manifested in their proficiency in verbal communication, meaningful interaction, and communication and information technology (Sudja \& Yuesti, 2017). More specifically, socially competent teachers demonstrate their social awareness, appreciation of knowledge, commitment to profession, loyalty to human dignity, as well as familiarity with relevant social and religious customs, culture, traditions, and aesthetics.

Finally, a professional teacher must be academically qualified, be physically and psychologically fit, and possess the aptitude to accomplish the national education goals. Yet, most importantly, he or she must hold an educator licensure as a formal evidence given in recognition of his or her professionalism (Harjanto et al., 2018). Mainly through the process of portfolio evaluation, those deemed to have met the aforementioned criteria will be certified and thus entitled to professional remuneration, benefits, as well as opportunities for career advancement (Haryanto et al., 2016).

Denim (2002) in Suprihatiningrum (2014) asserted that certification entails the official recognition by the state granted to a prospective person of profession who have completed the requirements and a competency test in the form of a certificate of acknowledgement of his or her aptitudes, credentials, and proficiencies, licensing his or her proficiency to offer educational roles in a given educational unit. For in-service teachers, certification is carried out mainly through portfolio assessment, teacher professional education and training, direct issuance of teacher certificates, or teacher professional education programs organized by tertiary institutions with accredited educational personnel procurement programs. As for pre-service teachers, provided that they have met all the certification criteria, the national government have given them the opportunity to be certified since 2007 by taking part in a series of competency tests carried out through a certification program at a designated accredited state teacher training institute (Kurniawan, 2011).

The quality of students is largely determined by the quality of the teacher and the learning process (Harris \& Sass, 2011; Kunter et al., 2013), in addition to their intelligence, interests, and efforts. Under this pretext, certification program principally aims to determine a teacher's eligibility in performing his or her teaching duties, enhancing the learning process and quality of its outcomes, and achieving national education goals. As for the teachers, certification not only increases their respectability and professionalism by revamping their welfare and working conditions, but also protects their profession from incompetent practices tarnishing its reputation. 
Above all, it serves to protect the community from inferior and unprofessional educational practices.

Pressure for certification has pervaded into both primary and secondary-school teachers in Indonesia, and EFL teachers, who endeavor to ensure their English language learners (ELLs) topnotch experiences in language instruction and curriculum standards, are not exempt from this inevitability. In Indonesia, EFL teachers are needed at all educational levels since English is learned not only at the primary level as an elective subject but also at secondary and tertiary levels as a required content, and accordingly, the demand for certified EFL teachers has risen exponentially. Indeed, never before has the need for certified Indonesian EFL teachers been more pressing. Indonesia is still ranked a lowly 15 out of 24 Asian nations in English proficiency, stuttering dramatically behind South Korea in $4^{\text {th }}$ position, Indian in $8^{\text {th }}$ and Pakistan in $11^{\text {th }}$ (English First, 2020). Indonesia is even outshined by Sri Lanka in 14th. This figure is by no means a positive sign for a country which has been adopting English as its first foreign language since the onset of its independence over 75 years ago (Suharjati, 2010). Therefore, a certification program is theoretically much needed to produce EFL teachers with decent pedagogical practices for dealing with ELLs. Certification serves as an evidence of an EFL teacher's exhaustive comprehension of the English language as well as an assurance that he or she is well-prepared to effectively facilitate the educational journey of his or her ELLs.

It has been almost fourteen years since the kickstart of teacher certification program in Indonesia, and the number of ESL teachers at primary and secondary schools in Indonesia is at an all-time high and ever-growing. Well over 97,000 EFL teachers have been registered (Kementerian Pendidikan dan Kebudayaan, 2016) out of more than three million school teachers, nearly half of whom have been certified. With the certification, it is expected that EFL teachers will have the capability to improve the quality of EFL learning at all levels at their disposals. Thus, this research seeks to investigate to what extent the Indonesia's teacher certification program affects the performance of the EFL teachers at secondary level.

A number of existing studies have examined the impact of teacher certification program on the improvement of teaching quality and the betterment of national education system. In English as a second language (ESL) field, Tran (2015) surveyed approximately 150 American ESL school teachers in her attempt to identify their attitude toward their training and their assumptions of their competence in teaching ELLs. Interviews and classroom observations were also conducted to add a qualitative depth to the data obtained from the questionnaire. Tran that knowledge on ESL teaching and learning the teachers learned during their teacher certification program significantly contribute to the effectiveness of their instructional practices. He also emphasized that education and training on ESL classroom strategies and teaching practices offered to pre-service teachers pursuing their teaching credentials are key factors in boosting ESL teachers' morale and fostering their competence.

In a study on certified teachers' performance in the United States, Lemberger and ReyesCarrasquillo (2011) surveyed over 60 certified bilingual education and ESL teachers in New York City. The study also involved interviews and observations on 18 of the teacher respondents in order to examine their classroom instructional practices. The findings suggested that through their application of a variation of powerful teaching methods and approaches, the certified teachers were able to retain ELLs' engagement and attention while demonstrating their remarkable appreciation for their ELLs' multicultural backgrounds. However, differences in teachers' understanding of teaching materials were encountered among the teachers especially in grade-level subject. 
Wiseman and Al-bakr (2013) scrutinized the impact of teacher certification on the campaign for educational overhaul in Gulf States. Based on the data acquired from a series of global assessments of students' mastery of mathematics and science in Gulf Cooperation Council (GCC) emirates, they empirically studied the correlation between teachers' licensing status in the six countries and the performance of their 8th grade learners in their achievement tests. They reported that there was no perceptible correlation between teacher certification and learners' improved academic accomplishment in particular and the standard of education in general. However, they perceived that even though a certification program is often directed at furthering a political interest, its benefit in fostering the habit of quality and planning among teachers should not be undermined.

In a research on the effect of certification on teacher motivation and performance in Indonesia, (Suratman et al., 2020) conducted a study on almost three hundred certified teachers in secondary schools and concluded that certification positively resulted in teachers' improved pedagogical practices, and the increased salary bonus it promises eased teachers' economic burden that often distracts them from fully performing their academic responsibilities. In line with this, (Abubakar, 2016), in his quantitative research on the relationship between teacher certification and quality of education in madrasa, reported a significantly positive effect certification brings on teachers' involvement in school program planning and implementation, improvement of learning quality, and teachers' competence. Relatively similar findings were also reported by (Taniredja \& Abduh, 2016), who examined the application of the four competencies in certified high-school teachers' teaching practice. Surveying thirty-nine certified teachers, the researchers concluded that certification has positively affects their pedagogical practices, with the social competence being their most prevalent characteristic.

Nevertheless, antithetical impact of certification have also been reported in numerous studies. Siswandari and Susilaningsih (2013), for instance, investigated the implementation of certified teachers' professional and pedagogical competencies in teaching and learning, involving in his research almost a hundred certified teachers, tens of principles and hundreds of students. The findings suggested that less than half of the certified teachers had the capacity to demonstrate their competencies in such aspects as lesson delivery and the use of multimedia. These results were in line with the findings from Kusumawardhani (2017) in her investigation of the significance of teacher licensure program toward learners' and teachers' achievement, performance, and commitment. She asserted that solid indication of the efficacy of licensure program on both teachers' and students' achievement, as proven in the calculation of their test and class participation stats. Her analysis was also reinforced by Fahmi et al. (2011), who compared the performance of the learners' taught by certified teachers and those taught by non-certified teachers in their national high-school exit tests by using Propensity Score Matching (PSM) and Differencein-Difference (DD) methods. Both procedures yielded identical results; teacher certification has little to no effect to their students' performance. The researchers also noted that in addition to promising rewards or extra income for certified teachers, a scenario for penalty should also be introduced for those who failed to perform as expected.

In Indonesia's EFL context, Buyung et al. (2013) conducted a mixed method research to explore the impact of certification on teachers' professionalism involving more than twenty certified English teachers from several madrasas from West Java. Through survey, observation, and document analysis, they suggested that all the certified teachers operate at a decent level of professionalism, as characterized among others by their well-developed lesson plan and wellimplemented lesson plans. Next, Anugerahwati and Saukah (2010), in their study of the features of model EFL teachers, conducted observations, survey and interview involving a number of 
model certified English teachers selected from several high schools in four towns in Indonesia. They found that the majority of the certified teachers are indeed proficient in their technical competencies, showing exceptional qualities especially in terms of their personal competence.

Nevertheless, a relatively questionable impact of EFL teacher certification have also been proposed by a few studies. Munfangati and Widodo (2014), for example, conducted a descriptive analysis research on the influence of certification requirements and teaching experiences on the performance of forty-three English teachers in twenty-two high schools in Indonesia. The results showed that both certified and non-certified teachers demonstrated relatively similar level of teaching quality. They found that rather than certification, teachers' experience is the more decisive factor contributing to better teaching performance. Similar results were also yielded by Zaim (2012), who, in his comparative analysis between certified and non-certified English teachers' performance, surveyed 16 non-certified and 20 certified high school English teachers with a questionnaire consisting of pedagogical and professional competence evaluation items. The findings revealed that no significant gap was identified in the level of pedagogical and professional competences of both certified and non-certified teachers, with the former in general exhibited only slightly better pedagogical and professional competence than non-certified ones. These findings were reiterated by Mahmudah (2013) in her comparative study of certified and non-certified teachers' pedagogical skills based on their achievement in standardized tests. She reported that both groups perform at the same level of functioning, with both relatively more competent at theoretical level of the teaching than at the implementation and assessment stages. In another analysis of learners' beliefs in their certified EFL teachers' competencies, Haryanto et al. (2016) mixed a quantitative and qualitative data acquired from a survey and group interview involving more than 90 high school ELLs as respondents. While the findings in the survey confirmed ELLs' acknowledgement of their teachers' competencies, the results of group interview proved that improvements need to be made in EFL teachers' personality and professional competences. Indeed, Lie et al. (2019) also reported disturbing findings in their investigation of the communicative aptitude of almost a hundred and fifty high school EFL teachers, fifty-two of whom were in the completion stage of their licensure program. The teachers' self-evaluation of their productive and receptive L2 skills, followed by a language aptitude test yielded a surprising discrepancy between the EFL teachers' perceived and real L2 communicative aptitude, signaling the ineffectiveness of teacher certification program and further raising the question on the criteria for its recruitment and graduation.

Thus, despite the fourteen-year-old certification program, only a handful of studies have been proposed on the impact of EFL teacher certification on the improvement teachers' performance and ELL instruction, and the results of these studies have been relatively contradictory. Therefore, more research on EFL teacher certification and its impact on their performance is gravely needed, especially one that also takes into account not only EFL learners' and school authorities' perspectives of the issue. The current research attempted to fill this gap.

\section{METHOD}

Methodologically, this study employed a descriptive research design through a qualitative approach, seeking to gain a comprehensive insight into a particular social phenomenon or human behavior through a method of naturalistic and contextual inquiry (Creswell \& Cresswell, 2017). As a case study, this research provided an analysis and in-depth investigation to a phenomenon within its real-life setting on single group - in this case the performance of certified EFL teachers at a prominent high school in Aceh Besar, Aceh. The subjects of this study were three certified 
EFL teachers, fifteen high-school EFL learners, and vice principal of curriculum. In selecting certified EFL teacher and EFL learner participants, purposive sampling method was used. The teacher participants in the school were selected based on two criteria; they have the longest teaching tenure, and they have been certified the longest. Meanwhile, the EFL learner participants were selected based on the criteria; they have been enrolled as students in the selected teachers' class, and they ranked the highest in their latest end-of-semester examination. The vice principle of curriculum affairs was selected from among the school authority since he is heavily involved with teacher performance assessment and in the school's biannual best-performing teacher selection, in addition to coordinating and directing the development and implementation of the curriculum and its components such as syllabus, assessment systems, learning models, grade promotion and graduation criteria, learning outcomes reports and analysis, learning completeness and yearly and semesterly learning programs (Benardi et al., 2018). Pseudonyms are used to refer to the participants. The data were collected by means of in-depth, semi-structured interview, observation, and document analysis, focusing on the analysis of teachers' instructional design which encompasses the development of teaching resources and experiences, their classroom implementation, as well as evaluation of instructional activities. To respond to the complexities of participants' feedback, unanticipated information, and to adapt to dynamics of research findings occurring particularly during the interview stage, this study employed an emergent design approach (Pailthorpe, 2017), thus carefully reevaluating and revising its elements, in this case interview questions, in data collection stage. The gathered data were organized, reviewed, analyzed and categorized into themes based on the aforementioned stage of instructional design.

\section{FINDINGS AND DISCUSSIONS}

The data obtained during the study were classified and discussed in general under the following themes:

\subsection{Lesson Planning and Development}

All the teacher participants spoke about their understanding of a decent lesson plan. One certified EFL teacher, identified as Ms. Sophia fluently outlined her ideal lesson plan and its necessities, stating:

A good lesson plan should be based on the current curriculum and syllabus. In developing a lesson plan, we have to take into consideration such components as time allocation, [and] standard of competence. Also, the indicators must correspond to basic competences. The teaching method should correspond with the materials and also the evaluation.

Analysis of the teachers' lesson plans following the interview confirmed that all the teacher's lesson plans have strictly adhered to the guidelines. Indeed, according to the revised curriculum 2013, commonly referred to as K13, core competencies are students' ability at each grade level or program to achieve graduate competencies. They govern all subjects and established that every subject contributes to the formation of learners' basic competencies, which constitutes a set of intellectual, personal, social, and emotional aptitudes a learner must develop in a particular subject based on his or her characteristics and initial abilities. The attainment of certain basic competencies at each level is measured through behavioral indicators which are designed as a reference for evaluating subjects (Machali, 2013). K13 also stipulates that a good lesson plan must comprise such components as course identity, core competence, basic competence, indicators, learning materials, time allocation, learning activities, learning sources, and assessment (Rindarti, 2018). 
Showing relatively a similar knowledge on lesson plan, another teacher, identified as Ms. Amelia mentioned the incorporation of the real needs of the learners in lesson plan development. She articulated this point declaring:

All the aspects such as time allocation, content materials, classroom activities, methodology, and evaluation should be based on the curriculum requirements and learners' needs.

A solid understanding of the needs of learners will lead to the effective planning of classes. Therefore, need analysis, the stage in which the ESL teacher identifies what specific language needs and skills are required by the learners, is of utmost importance. Need analysis promises learners benefit in short term by helping them succeed in the learning process they participate in and in long term in the profession or job they will pursue in the future (Hariyadi \& Yanti, 2019). Questioned further on how his need analysis was conducted, Ms. Amelia indicated that his need analysis was conducted by mainly formal and informal consultation with fellow teachers (Nation \& Macalister, 2019).

Mr. Liam, the other certified ESL teacher, while showing the same mastery of lesson development, expressed his relaxed adherence to his lesson plan and the frequent need for him to adjust or improvise, explaining:

In the classroom implementation, sometimes your lesson doesn't go according to the plan. While we may intend to stick to our lesson plans, the reality is there are times when your lesson just doesn't go as planned. It's just out of your hands.

Mr. Liam's concern over the actual classroom implementation of a lesson are well-expressed since it is not uncommon for a thoughtfully crafted lesson plan to stray away drastically from what was initially intended. keeping up with the design while dealing with individual student's characteristics and competencies, classroom disruptions, and external interference can be demanding. Despite teachers' attempt to adhere to their lesson plans, the harsh fact is on most occasions their plans may not be implemented thoroughly. Teachers have been reported to deviate from their lesson plan for such reason as keeping the learning going, facilitating different learning styles, encouraging learner's engagement (Gün, 2014), dealing with disruptive conduct (Sougari, 2011) or adapting classroom content with students' current knowledge state (Shalem et al., 2017).

The vice principal of curriculum affairs, identified as Mr. Noah, confirm the teachers' qualifications in constructing proper lesson plans. He acknowledged that during his tenure, almost all certified EFL teachers in the school, including the three in this study, have been strongly committed to preparing their syllabus, course design, and lesson plan at the start of each term. Their documents have also been on par with the demand of the national curriculum. However, he admitted:

Some certified teachers' lesson plans self-made, in part or in whole. Consequently, the adopted lesson plans fail to recognize the students' distinct needs and personalities. So, the function of a lesson plan is only limited to fulfilling school administration requirements, rather than carrying out teaching commitment and responsibilities.

Some certified teachers' lesson plans self-made, in part or in whole. Consequently, the adopted lesson plans fail to recognize the students' distinct needs and personalities. So, the function of a lesson plan is only limited to fulfilling school administration requirements, rather than carrying out teaching commitment and responsibilities.

A lesson plan helps ensure that learners undergo effective and engaging learning experience in the classroom. It also helps the teachers to stay on their path of ensuring the achievement of learning expectations and objectives, in accordance with the course curriculum. However, some teachers have admitted that reporting that creating inspiring lesson plans can seize a large amount 
of their time and effort (Apsari, 2018). However, while teachers might be tempted to opt to reference ready-made lesson plan in circulation, teachers should recognize that the lesson plan should be developed according to the needs and characteristics of learners, schools, subject areas, and regional potential in order to encourage learners' active engagement and provide ample room for their creativity and autonomy based on their talents, interests, as well as physical and psychological development.

\subsection{Lesson Planning and Development}

Observation revealed a partial mismatch between Ms. Amelia's lesson plan and her classroom implementation. However, Ms. Amelia managed to engage her learners in some researchsupported activities and practices such as role-play, critical thinking exercises, problem-solving exercises, high-quality discussions, story-telling, online research, and games, in his instruction on oral and written production of the language, reading and listening comprehension, as well as grammar and vocabulary development. The learners also made it very clear that they appreciate the clarity of Ms. Amelia's delivery, as one learner, identified as Ella, acknowledged:

We like the way she delivers the lesson; she explains it clearly and it becomes easy for us to understand the materials.

Ms. Amelia's use of varied sources of materials was also elaborated by at least three interviewed ELLs, one of whom, identified as Benjamin, pointed out:

She uses the materials from our textbook, students' handbook, and sometimes she brings her own materials from the internet and so on. She understands the materials well because she can explain them clearly.

In post-class interview, Ms. Amelia highlighted the need to facilitate learners' different styles of learning by employing a variety of teaching approaches and methods, stating:

In [classroom] implementation, it is impossible to stick to one approach that works for a group of learners and use it for any other group of learners. So, we may have to select from a collection of methods one that best suit a particular group of the learners. Even in one classroom, learners come with a varying learning styles and abilities. Therefore, the approaches will have to be varied because all students need to learn.

It is imperative for language teacher to master the different methods and techniques so that they can make informed decision, and increase their learner's pleasure of studying English. Teachers should therefore recognize all of the methodologies in depth and determine which one works well in a given context in which they operate. Indeed, EFL nowadays is often taught through an eclectic approach (Alharbi, 2017; Biloon, 2016; Cushing-Leubner \& Bigelow, 2014), in which teachers use techniques and activities derived from a variation of approaches and methodologies by deciding what best suits particular lesson objectives and learners' needs. Different learners come to the class with different backgrounds and interests, so teacher need a versatile way to accommodate all of them as there is no method that can be implemented in any situations with any type of learners.

Frequent comprehension checks (Cervantes \& Rodriguez, 2012; Krashen \& Mason, 2019; Namaziandost \& Imani, 2020) were noticeably a distinct characteristic of Ms. Amelia's classroom instruction. It was evident she was reluctant to move on until all the learners have a solid grasp on the content. She noted:

I constantly observe how the learners responded to me because I want to be sure that I and my lessons are comprehensible. I try to make sure that my students can make sense of my course materials, so I like to use authentic sources to gain their interests. 
In completing language tasks, the ELLs in her class benefit from a mixture of pair and group work. Students were put in pairs or groups for a variety of tasks, including checking answers, playing games, role-play, or surveys. This learner-centered approach was well appreciated by the learners, two of whom stated:

Sometimes we have to complete a task individually, but in her class [we] frequently work in pairs or in groups. Working with other students is enjoyable, and we learn from each other, too. (Henry)

I remember once she asked the students to sit in groups, read the text to each other, and had a small group discussion on summarizing the text. None of us fully comprehended the text, but when we worked together, we exchanged what we understood, and in the end we all could get the complete comprehension of the text. (Leo)

Pair work and group work have been shown to have a myriad of advantages not only for teachers but also for the learners (Clapper, 2015; Fani \& Ghaemi, 2011; Igel \& Urquhart, 2012; Vygotsky, 1964; Zulfikar \& Aulia, 2020). Not only does learners' active involvement in such cooperative learning models enhance their language acquisition, but when managed appropriately, it saves time, provides the opportunity for the learners for practicing the language more, empowering them to learn from one another, promote autonomous learning, promote collaborative learning, and boost learners' confidence. By working with their peers, learners will learn from and with each other by clarifying and consolidating their ideas and opinions. Nonetheless, teachers should make sure that group or pair works do not go out of hands as it is not uncommon for students who work with peers to excessively correct each other's mistakes, use their native language for interaction, and eliminate weak students from participating and engage in social loafing (Bishnoi, 2017; Govindasamy \& Shah, 2020; Ibrahim et al., 2015; Watanabe \& Swain, 2008).

Thus, Ms. Amelia demonstrated her proficient mastery of the materials, showcased decent use of media, interactively involves with the whole class in learning, skillfully used a selection of strategies, provided contextual examples, and gave reinforcement for student responses or answers. Students are very motivated in participating in teaching and learning activities so that the learning atmosphere is very pleasant.

In contrast, an outward deviation from the lesson plans was observed in the other two teachers' classroom instructions. Most noticeable was the absence of the use of varied media as instructional resources to enhance EFL learning experiences, with the teachers resorting to the use of textbook throughout the classes.

It was visible during the observation that Mr. Liam's overreliance on textbook makes her lessons less engaging. The learners reiterated this point, asserting:

We [are] always [directed to] translate a text after reading it. Then the teacher asks to complete a task. We think this method is too boring and sometimes doesn't suit the materials because we know the meaning of the whole text before we answer the questions. (Henry) We always use our handbook. There's a text [we have to read], and there is some explanation [from her]. (Nora)

In addition, despite of proficient mastery of instructional materials, Mr. Liam exhibited her preference of using learners' L1 as the classroom language. As the learners asserted:

When she starts the class, she never greets us in English, but her explanation is really clear and easy to understand. (Luna)

When she explains the lessons, I think she really masters them although the explanation is in Indonesian. (Nora) 
Many English Language Teaching researchers advocate that L1 can play a facilitating role in the teaching of English L2 (Carson \& Kashihara, 2012; Grim, 2010; Lightbown \& Spada, 2020; Zulfikar, 2019), implying that teachers who speak learners' L1 are at an advantage especially when dealing with learners who all speak the same L1. However, excessive L1 use can be counterproductive in second or foreign language learning as it may hamper learners' acquisition of the target language. In EFL classroom, teachers must bear in their mind that they are the learners' best resources for acquisition, so teachers must always use L2 when possible, and L1 only when necessary. For instance, in a beginners' classroom, a lesson may be introduced with a combination of L1 and L2 with gradual surge in the use of English as the learners are progressing. The overuse of L1 as a classroom language, as Mr. Liam demonstrated, in learning English could create a crutch that may be very hard to shake off; that is, both learners' and teachers' over-dependence on it.

As for Ms. Sophia, observation showed her adoption of a strictly teacher-centered method for most of her classroom instruction. The learners looked disinterested and passively engaged throughout the lesson since she delivered the instruction directed by her. The teacher was so fixated on the book that learning seemed monotonous, with the teacher visibly lacking in strategies and the learners in enthusiasm. Moreover, in her class, student handbook was also used disproportionately as the only learning resource, and translating texts into learners L1 looked to be most common exercise assigned to students. Thus, in her case, our observations of the classroom environment did not match her perception of her ability in using relevant instructional materials and resources. The teacher initially declared himself as a resourceful ESL teacher, but a translation and grammar-based instruction directly from the textbook was performed by the school's longest serving ESL teacher right from the outset. Although students did the tasks given, they did not seem engaged and most of them cut bored figures. In the post-observation interview, the teachers justified her decision to "occasionally" setting up translation activities in her classroom, asserting:

Perhaps, because of the students' [poor level of] English in this school we often simply ask them to translate an English text and answer the [comprehension] questions [about the text] afterwards.

Unsurprisingly, the learners spoke about their dissatisfaction to her approach, stipulating:

Translate, translate, and translate. [We are instructed to] open our handbook, look for the text on page something, read, and translate it. (Ella)

In the end what we do is just translating the text into Indonesian. We think the method should change because it doesn't work, [but] we are always learning English that way. (Layla)

While textbooks offer several advantages for both teacher and learners (McGrath, 2013; Tok, 2010; Wen-Cheng et al., 2011), they are only as good as the teachers who utilize them. Teachers should avoid over-relying on them so as to fail to consider other teaching aids or materials for the classroom. Indeed, the utilization of effective learning aids and resources are essential in every classroom to develop skills and learning experiences that are relevant and meaningful to learners. Teaching aids serve a variety of purpose such as skill or concept illustration or reinforcement (Foote et al., 2012), affective filter reduction (Macwan, 2015), and innovative lesson presentation (Halwani, 2017).

Other learners also expressed their discontent on Ms. Sophia's content knowledge and delivery, testifying that her lesson presentation is "hard to understand" (Mia, Luna, and Aria), "often unclear" (Henry), and thus they "can only understand some portion of it" (Mia, Luna, Julian, and Dylan). Learners' disappointment was best summed up by Luna, who said:

Materials are always taken from student handbook, and I also feel hard to understand the explanation. 
Post-observation, questioned on her believe on her classroom practice, the teacher argued that it all came down to the lack of motivation her ELLs possess, indicating that her teacher-centered approach was her solution for the learners' interest in learning by asserting:

There is no such thing as good method if the learners have no motivation to study. This is true not only in learning English but also all other subjects. It becomes difficult to teach them. So, when we teach English, just give them a little explanation and ask them to work individually although working in group is good for them sometimes.

Nonetheless, two of the observed teachers saw motivation as having a substantial impact on their ELLs' learning. Mr. Liam sparked her ELLs' desire to learn by sharing her enthusiasm for learning, telling them the joy and excitement learning has brought to her life while Ms. Amelia positively directed her ELLs' attention to herself in the beginning of class by specifying clearly how the lesson relates to their future routines. Ms. Amelia, in particular, was also observed to frequently motivate her learners by recognizing and celebrating their achievements (Rahimi \& Karkami, 2015; Ripollés et al., 2014), using humors (Bell, 2011; Reddington, 2015; Ziyaeemehr et al., 2011), and constantly praising her learners with “Thumbs up!", “Good job!", or "I knew you could do it." (Jenkins et al., 2015; Skipper \& Douglas, 2012). Mia's comment best represented the ELLs' approval of Ms. Amelia particular classroom practice, stating:

She often motivates us before we start learning. I become very enthusiastic after that. He also makes jokes at times. We always look forward to listening to his jokes. They help us regain ourfocus.

This classroom practice as exhibited by the two teachers has been well-documented in the studies which have consistently shown that motivation is the single most significant predictor of an individual's successful academic performance (Steinmayr et al., 2018; Weber et al., 2013; Wigfield et al., 2016). Motivated learners will make an extra effort in their learning. Learners who are intrinsically motivated find the delight in learning because it gives him or her gratification and personal satisfaction while those who are extrinsically motivated are driven in their learning by a particular outcome or objectives he will gain through learning. Indeed, among the main hurdles for teachers and educators alike is to devise a way to foster learners' curiosity and thirst for knowledge, nurturing enthusiasm of creativity and innovation that contribute to the accomplishment of their aspirations and a feeling of satisfaction. Learners must recognize the value of being committed to improve, the link between performance and results in education, and the repercussions of struggling to identify the motivation to pursue something positive and valuable in their lives.

These two teachers were able to promote conducive learning environment which can stimulate students' enthusiasm and motivation. As a result, teachers and learners maintain good relationship and healthy interaction, which also translated into similarly well-maintained relationship inside and outside the class. Indeed, one learner, identified as Ezra, voiced his opinion on Ms. Amelia, stating:

We feel comfortable asking questions and voicing opinions during the class. Whenever we feel we don't quite understand [the materials], the teacher will gladly re-explain them. Outside the classroom, the teacher is sociable and sympathetic, so we never hesitate to greet them.

Interview with the ELLs also revealed the counseling services Ms. Liam provided to underperforming students, as depicted by Luna:

She motivates us every now and then, usually by telling stories about herself or successful people. And sometimes she also invited some poor or underperforming students for counseling . 
Counseling helps learners recognize themselves; their strengths and weaknesses, so as to guide them toward confidence, changes, successes, and better performance (Adebowale, 2012; Chan \& Quinn, 2012; McKenzie et al., 2015). Underperforming students can especially use the help of a teacher to increase their motivation and proficiency through counselling sessions during which teachers can help their learners learn the significance of setting objectives and accomplishing them. It is the responsibility of educators to assess the factors which influence individual learner's lives and select strategies that have the potential of helping these students to become more motivated to achieve. The teacher-learner social relationship as depicted above provides the learners with interpersonal supports and an opportunity to perform better academically and to augment the learning process beyond the classroom (Dotterer \& Lowe, 2011; Graziano et al., 2007; Košir \& Tement, 2014; Sointu et al., 2017).

The principle offered a relatively similar perspectives on the ESL teachers. While he had noticed some innovation in the way Ms. Amelia conducted teaching and learning through the incorporation of technology in learning, well up-to-date learning materials, and engaging techniques, there has been no "obvious" changes in the way Ms. Sophia and Mr. Liam teach. He stipulated that it is not uncommon to find certified teachers who use conventional learning models in providing teaching materials to learners. In fact, according to him, some certified teachers believe they no longer need to add to their qualifications and knowledge because they think certification is the end. However, in the case of Ms. Sophia and Mr. Liam, he believed that like all other EFL teachers in the school, they have acquired enough knowledge and have been well experienced in ESL teaching pedagogies, it was their willingness, or lack of it, that often stands in the way of them applying all their knowledge in the classroom. As he asserted:

Knowing is one thing, but doing is another thing.

With the additional incentives received by certified teachers in Indonesia, it may seem inconceivable to find learn that some of them still suffer from motivational crisis since excellent teachers should be driven by their enthusiasm for student learning. While there are a number of factors contributing to lowered teacher motivation (Han \& Yin, 2016; Nawaz \& Yasin, 2015), this fact seemed to support the notion that while certification guarantee teachers' satisfaction and financial conditions, it does not always bring about an improvement in their performance (Fahmi et al., 2011; Mahmudah, 2013; Wiseman \& Al-bakr, 2013). Furthermore, in addition to indicating the absence of a clear mechanism of observing how teachers demonstrate their competence in the classroom (Haryanto et al., 2016; Ramli, 2014), this case also marks the failure of certification program to ensure the improvement of teaching and learning in the classroom level (Kusumawardhani, 2017). More importantly, one thing is for sure; this lack of commitment may negatively affect their learners' performance, as studies have suggested (Altun, 2017; Mahler et al., 2018; Park, 2005). Committed teachers are distinguished by their passion for innovative ideas, devotion commitment to make an impact on learners' academic success, as well as commitment to improve their own potentials and credentials.

As far as Ms. Sophia is concerned, the principal continued, lateness and discipline are still among her issues. Students have been reporting that the teacher sometimes arrives late to the classes, and leaves early. In fact, the record showed that she had been skipping the classes more than once. The principal was worried of the bad example the teacher may set to her learners their tardiness, maintaining:

This behavior is not a trait of a socially-competent teacher. Any certified teacher who is not disciplined is a poor model for their students and fellow teachers and should figure out a suitable way to remedy this type of unprofessional conduct. 
Teachers who turn up prepared and on time show that they take their duties seriously. Slacking off and arriving late will likely result in disappointed students and school administrators. In addition, instructor's showing up on time would discourage any students from causing disturbances or disruptions. It is also to the benefit of the instructor because the feelings of relaxation will lead to effective learning. In fact, teacher's punctuality and absenteeism directly bring about discipline issues among learners (Butakor \& Boatey, 2018; Gata et al., 2019; ShapiraLishchinsky, 2011). Ms. Amelia's case, therefore, reflects her lack of personality competence (Haryanto et al., 2016; Mahmudah, 2013). Punctuality among teachers is a measure of selfdiscipline and commitment to serving and providing students with knowledge. When students are impressed with a teacher, they learn from him. Teachers serve as a role model in the education system who not only disseminate knowledge, but also motivate, inspire and educate their learners. Profession of an educator requires a teacher to be skilled not only in the transfer of knowledge, but also in the transfer of value.

\subsection{Learning Evaluation}

Assessment helps both teachers and students to track progress towards the successful accomplishment of learning goals, and can be implemented in a wide variety of methods (Brown \& Abeywickrama, 2018). A teacher uses formative assessment along the course of learning to determine learners' misassumptions, shortcomings, difficulties and discrepancies as well as solutions to cut them down. On the other hand, a teacher uses summative assessments at the conclusion of an instructional cycle in order to evaluate learners' knowledge and proficiency or course outcome.

Ms. Amelia employs a wide range of evaluation and assessment in her class involving both selected and constructed assessments (Kırkgöz \& Ağçam, 2012). Selected response assessment includes multiple-choice, matching, true-false tests, while constructed assessments include essays, open-ended and performance tasks. The teacher was also able to present the supposedly tedious tests in a more interesting way by combining the test with physical activities. In a matching, exercise, for instance, the students were grouped into two and each group makes a line and students from each group takes turn hitting true-or-false options on the board after the teacher diligently display the prompt using the projector. This way the students need to not only choose right but also choose fast. The class was lively and the students could be seen stimulated. The same is true for word reordering exercise, during which the learners in group compete to become the first to create the structurally correct sentence and to get the most sentences correct. Learners could be seen running back and forth to their teachers checking their answers with the teachers checking their sentence accuracy. Breaking away from traditional classroom activities, teacher also presented quizzes and reviews more engagingly using such technology as Kahoot! and Quizziz (Martínez-Jiménez \& Ruiz-Jiménez, 2020). These game-based learning platforms can enhance dynamics in the classroom and created a more supportive educational experience, resulting in greater classroom participation, student engagement, enthusiasm, and cooperation between learners and teachers and students and peers. As one learner, identified as Levi, remarked:

This teacher often gives us enjoyable and interesting exercises. I especially like Kahoot! session.

Instead of taking control of the entire learning process, Ms. Amelia in this case assumed the role of a facilitator, who lets the learners discover and take charge of their own learning, occasionally responding to unexpected instructional difficulties faced by the learners during exercises. 
Ms. Amelia also used alternative assessment (Coombe et al., 2012) such as oral presentations (role-plays and interviews) and non-verbal assessment such as charades and in-class discussion. In performance tasks, the learners were given a topic and prepare a set of questions they will use to interview their partners before eventually presenting their findings to the class. For ELLs, alternative assessment offers many benefits as they provide ways to evaluate skills that cannot be authentically and comprehensively assessed with conventional assessment (Zulfikar, 2016). Of course, that is not to say that traditional assessment should be abolished completely from the classroom. Both offer a wide range of selection of assessment means which allows the teacher to obtain an accurate image of the learners' language proficiency.

Ms. Sophia and Mr. Liam, nonetheless, demonstrated their overreliance to the tasks provided in the students' handbook for their daily formative evaluation, which included gap-filling exercises, open-ended comprehension questions, multiple choice, and true-false or matching exercises, with translation exercise being the most commonly assigned in Ms. Sophia's classroom in particular. Arguably, appropriate implementation of translation exercise might allow learners to benefit from the enrichment of their syntactic and semantic knowledge (Al-Musawi, 2014; Dagiliené, 2012), but this only occurs when learners are encouraged to identify variations in grammatical and lexical items. A translation task may decrease the possibility of the learners, especially those at upperlevel (Payne \& Contreras, 2019), to obtain adequate L2 input. This is because it normally seizes a significant amount of class time, allowing learners a prolonged use of L1, which contradicts the purpose of learning in modern EFL and ESL pedagogy; that is, to eliminate the use of L1 in language instruction. Subsequently, most of the interviewed students express their dissatisfaction on this evaluation method. Among them, two were quoted as saying:

Translating the text in our handbook is the first task she gives. Then we answer the questions that follows the text. This assignment doesn't take us anywhere [there is no point in doing this assignment this way] because if we know the translation of the text, it's easy to answer the questions. (Mia)

He always asks to translate the text that we read. It helps us understand the main ideas of the text. Then we create our own questions based on the text and provide our own answers for them. I don't quite understand how we are supposed to learn from doing this. (Ezra)

In their classes, in general all tasks were usually to be completed individually by the learners. Working together were only allowed after tasks were completed to check and compare each other's responses before the teacher finally called up the learners to read out their answers. Correction was prompted from other learners, and in case no correct responses were provided by any learner, the teacher themselves would provide the answer. Thus, in term of evaluation, assessment of learners' language proficiency was made based on how well they can complete the tasks provided in their handbook, as Luna pointed out:

Sometimes, Ms. Sophia directs us to create some questions based on the text, then answer them ourselves or exchange them with other students. We always translate texts and we cannot get the point of materials after the lesson.

Nevertheless, interview revealed that all three teachers share the same type of summative assessment; they resort to the use of multiple-choice items for both mid-term and end-of-term evaluation. While items for mid-term test was designed by themselves, regional English teacher consortium was in charge of composing the multiple-choice questions for end-of-term examination. All three certified teachers believed that the use of multiple-choice question type for final evaluation has been stipulated by the national educational board. While admitting the downsides of multiple-choice question - its relatively time-consuming formulation (Odukoya et al., 2018), its 
inability to assess students' critical thinking (Zaidi et al., 2018), and its low positive washback (Stanger-Hall, 2012) - both of them agreed that teacher benefits from the ease her in scoring, especially considering the administrative burdens which usually piles up at the end of term.

The vice principle contended that in conducting the assessment, only a few certified teachers in the school employed assessment tools in accordance with the predetermined learning objectives, with Amelia being one of them. However, he found that most teachers' - certified or non-certified - assessment scheme still strays away from the indicators of the achievement of competency standards and basic competencies of each subject. In contrast with the certified teachers' statement, the vice principle stated that there was no regulation at either national and regional levels that constraint teachers' freedom to select their types of formative or summative assessment, including the use of multiple choice in examinations. Nevertheless, he believed that the teacher consortium collectively agreed on using multiple-choice for learners' examination due to the ease of scoring it offers. Indeed, indicators serve as guidelines in designing, implementing, and evaluating learning outcomes (Triwiyanto, 2013). The assessment design provides a reference in determining the form and type of assessment, as well as the development of assessment indicators. The development of assessment indicators must refer to the achievement indicators developed in accordance with the demands of standard of competency and basic competence. Indicators themselves are developed in accordance with the need assessment taking into account students' characteristics, educational units, as well as local wisdom and regional potentials (Hidayah et al., 2017). Thus, indicators have a very strategic position in achieving competency since they can provide an overview of effective learning activities.

\section{CONCLUSION}

It was interesting to discover that every so often the results of teachers' interviews are not consistent with the findings in the observations. This could be attributed to the open nature of the interviews, which may have seized the teachers' attention away from the emphasized areas in the literature. Therefore, more focused interviews after the observations were conducted to seek a greater effectiveness.

To summarize, results from this study showed that only one out of three observed certified EFL teachers had a positive rapport with their ELLs, owing to the fact that their instructional beliefs predominantly do not align well with the observed instructional practices and fail to denote to various extent evidence-based ELL strategies. The findings suggested that one certified EFL teacher was well-equipped with the noteworthy competencies, demonstrating her exemplary enthusiasm and commitment which reflected her tremendous professionalism and devotion to her learners. While in the interviews she left an impression of her competence, her research-based classroom practices confirm her prowess in effective ELL pedagogy.

Two other observed certified teachers exhibited instructional practices that the research does not completely sanction, adopting whole-class instruction and teacher-centered approaches as the primary framework of teaching. These findings alarm us that in spite of the solid evidence-based literacy in that highlight best practices to support ELLs, traditional methods of teaching continue to be prevalent with much less application of active learning strategies than required. Accordingly, the findings also served as an evidence that teacher certification does not necessarily translate to improvement in the quality of service, and that even some EFL certified teachers still wind up teaching ineffectively.

Nonetheless, the current study with all its limitations certainly cannot provide a conclusive evidence to mixed impact of certification, and the debate over whether certification results in 
improved teacher performance and students' achievement will persist. Perhaps, With the suggested approach in this research involving numerous observations, far-reaching surveys, as well as administrative database, a richer understanding of the impact of certification can be acquired.

\section{REFERENCES}

Abubakar, A. (2016). Dampak sertifikasi guru terhadap kualitas pendidikan pada madrasah aliyah di kota Kendari [The impact of teacher certification on the quality of education at Islamic high schools in Kendari city]. Al-Qalam, 21(1), 128. https://doi.org/10.31969/alq.v21i1.204

Adebowale, T. A. (2012). Guidance and counselling in the sustainability of educational system. African Research Review, 6(2), 215-225. https://doi.org/10.4314/afrrev.v6i2.19

Al-Musawi, N. M. (2014). Strategic use of translation in learning English as a foreign language (EFL) among Bahrain university students. Comprehensive Psychology, 3, 10.03.IT.3.4. https://doi.org/10.2466/10.03.IT.3.4

Alharbi, S. H. (2017). Principled eclecticism: Approach and application in teaching writing to ESL/EFL students. English Language Teaching, 10(2), 33-39. https://doi.org/10.5539/elt.v10n2p33

Altun, M. (2017). The effects of teacher commitment on student achievement: A case study in Iraq. International Journal of Academic Research in Business and Social Sciences, 7(11), 51-54. https://doi.org/10.6007/IJARBSS/v7-i11/3475

Anugerahwati, M., \& Saukah, A. (2010). Professional competence of English teachers in Indonesia: A profile of exemplary teachers. In Indonesian Journal of English Language Teaching (Vol. 6, Issue 2). https://doi.org/10.25170/IJELT.V6I2.1545

Apsari, Y. (2018). Teachers' problems and solutions in implementing curriculum 2013. Acuity : Journal of English Language Pedagogy, Literature and Culture, 3(1), 11-23. https://doi.org/10.35974/acuity.v3i1.620

Bell, N. D. (2011). Humor scholarship and TESOL: Applying findings and establishing a research agenda. TESOL Quarterly, 45(1), 134-159. https://doi.org/10.5054/tq.2011.240857

Benardi, A. I., Purwaningsih, W., \& Rahima, H. N. (2018). Analisis standar pengelolaan peran pendidik dalam proses pembelajaran IPS di SMP N 1 Karimunjawa, MTs dan MA NU Safinatul Huda Pulau Karimunjawa [Analysis of management standards of teacher role in social studies learning at SMP N 1 Karimunjawa, MTs and MA NU Safinatul Huda in Karimunjawa island]. Jurnal Profesi Keguruan, 4(2), 110-116. https://doi.org/10.7290/jpk.v4i2.17000

Biloon, J. R. S. (2016). The use of the eclectic method in an English language classroom for learning specific skills. Journal of English Education, 1(2), 140-146.

Bishnoi, N. (2017). Collaborative learning: A learning tool advantages and disadvantages. Indian Journal of Health and Well-Being, 8(8), 850-852.

Brown, H. D., \& Abeywickrama, P. (2018). Language assessment: Principles and classroom practices (3rd ed.). Pearson Education.

Butakor, P. K., \& Boatey, B. O. (2018). Supervision of teacher's punctuality and students' 
attendance in senior high schools: Exploring the views of students. Journal of Education and Practice, 9(30), 71-79.

Buyung, B., Marhaeni, A. A. I. N., \& Dante, N. (2013). Analisis tentang profesionalisme guru studi kasus pada guru-guru Bahasa Inggris sertifikasi pada madrasah aliyah di Kabupaten Lombok Barat [Analysis of teacher professionalism: a case study of certified English teachers at Islamic high schools in West Lom. E-Journal Program Pascasarjana Universitas Pendidikan Ganesha, 1, 1-9. https://doi.org/10.23887/jpbi.v1i0.883

Carson, E., \& Kashihara, H. (2012). Using the L1 in the L2 classroom: The students speak. The Language Teacher, 36(4), 48. https://doi.org/10.37546/jalttlt36.4-5

Cervantes, C. A. R., \& Rodriguez, R. R. (2012). The use of communication strategies in the beginner EFL classroom. Gist Education and Learning Research Journal, 6, 111-128.

Chan, S., \& Quinn, P. (2012). Secondary school students' views of inhibiting factors in seeking counselling. British Journal of Guidance \& Counselling, 40(5), 527-543. https://doi.org/10.1080/03069885.2012.719603

Clapper, T. C. (2015). Cooperative-based learning and the zone of proximal development. Simulation \& Gaming, 46(2), 148-158. https://doi.org/10.1177/1046878115569044

Coombe, C., Davidson, P., O'sullivan, B., \& Stoynoff, S. (2012). The Cambridge guide to second language assessment. Cambridge University Press.

Creswell, J. W., \& Cresswell, J. D. (2017). Research design: Qualitative, quantitative, and mixed methods approaches (4th ed.). SAGE Publications, Inc.

Cushing-Leubner, J., \& Bigelow, M. (2014). Principled eclecticism and the holistic approach to language teaching and learning. In S. Çelik (Ed.), Approaches and Principles in English as a Foreign Language (EFL) Education (pp. 254-263). Eğiten Kitap. https://citeseerx.ist.psu.edu/viewdoc/download?doi=10.1.1.707.1869\&rep=rep1\&type=pdf

Dagiliené, I. (2012). Translation as a learning method in English language teaching. Studies About Languages, O(21), 124-129. https://doi.org/10.5755/j01.sal.0.21.1469

Dotterer, A. M., \& Lowe, K. (2011). Classroom context, school engagement, and academic achievement in early adolescence. Journal of Youth and Adolescence, 40(12), 1649-1660. https://doi.org/10.1007/s10964-011-9647-5

English First. (2020). EF english proficiency index: A ranking of 100 countries and Regions by English Skills. www.ef.com/epiwww.efset.org

Fahmi, M., Maulana, A., \& Yusuf, A. A. (2011). Teacher certification in Indonesia: A confusion of means and ends (No. 201107).

Fani, T., \& Ghaemi, F. (2011). Implications of Vygotsky's zone of proximal development (ZPD) in teacher education: ZPTD and self-scaffolding. Procedia - Social and Behavioral Sciences, 29, 1549-1554. https://doi.org/10.1016/j.sbspro.2011.11.396

Foote, J. A., Holtby, A. K., \& Derwing, T. M. (2012). Survey of the teaching of pronunciation in adult ESL programs in Canada, 2010. TESL Canada Journal, 29(1), 22. https://doi.org/10.18806/tesl.v29i1.1086

Gata, W., Grand, G., Fatmasari, R., Baharuddin, B., Patras, Y. E., Hidayat, R., Tohari, S., \& 
Wardhani, N. K. (2019). Prediction of teachers' lateness factors coming to school using c4.5, random tree, random forest algorithm. 2nd International Conference on Research of Educational Administration and Management (ICREAM 2018), 161-166. https://doi.org/10.2991/icream-18.2019.34

Govindasamy, M., \& Shah, P. M. (2020). Students' perceptions on collaborative speaking tasks in ESL classrooms. Creative Education, 11(11), 2280-2292. https://doi.org/10.4236/ce.2020.1111167

Graziano, P. A., Reavis, R. D., Keane, S. P., \& Calkins, S. D. (2007). The role of emotion regulation in children's early academic success. Journal of School Psychology, 45(1), 3-19. https://doi.org/10.1016/j.jsp.2006.09.002

Grim, F. (2010). L1 in the L2 classroom at the secondary and college levels: A comparison of functions and use by teachers. Electronic Journal of Foreign Language Teaching, 7(2), 193-209.

Gün, B. (2014). Making sense of experienced teachers' interactive decisions: Implications for expertise in teaching. International Journal of Instruction, 7, 75-90.

Hakim, A. (2015). Contribution of competence teacher (pedagogical, personality, professional competence and social) on the performance of learning. The International Journal of Engineering and Science, 4(2), 1-12.

Halwani, N. (2017). Visual aids and multimedia in second language acquisition. English Language Teaching, 10(6), 59. https://doi.org/10.5539/elt.v10n6p53

Han, J., \& Yin, H. (2016). Teacher motivation: Definition, research development and implications for teachers. Cogent Education, 3(1), 1217819. https://doi.org/10.1080/2331186X.2016.1217819

Hariyadi, A., \& Yanti, D. R. (2019). The Importance of needs analysis in materials development. Jurnal Ilmiah Profesi Pendidikan, 4(2), 94-99. https://doi.org/10.29303/jipp.v4i2.88

Harjanto, I., Lie, A., Wihardini, D., Pryor, L., \& Wilson, M. (2018). Community-based teacher professional development in remote areas in Indonesia. Journal of Education for Teaching, 44(2), 212-231. https://doi.org/10.1080/02607476.2017.1415515

Harris, D. N., \& Sass, T. R. (2011). Teacher training, teacher quality and student achievement. Journal of Public Economics, 95(7-8), 798-812. https://doi.org/10.1016/j.jpubeco.2010.11.009

Haryanto, E., Mukminin, A., Murboyono, R., Muazza, M., \& Ekatina, M. (2016). Teacher certification policy: Evidence from students' perception on certified English teachers at one public high school in Jambi Indonesia and policy implications. Turkish Online Journal of Qualitative Inquiry, 7(3). https://doi.org/10.17569/tojqi.31703

Hidayah, R., Salimi, M., \& Susiani, T. S. (2017). Critical thinking skill: Konsep dan indikator penilaian [Critical thinking skill: Assessment concepts and indicators]. Jurnal Taman Cendekia, 1(2), 127-133. http://dx.doi.org/10.30738/tc.v1i2.1945

Ibrahim, N., Shak, M. S. Y., Mohd, T., Ismail, N. A., Perumal, P. D., Zaidi, A., \& Yasin, S. M. A. (2015). The importance of implementing collaborative learning in the English as a 
second language (ESL) classroom in Malaysia. Procedia Economics and Finance, 31, 346-353. https://doi.org/10.1016/s2212-5671(15)01208-3

Igel, C., \& Urquhart, V. (2012). Generation Z, meet cooperative learning. Middle School Journal, 43(4), 16-21. https://doi.org/10.1080/00940771.2012.11461816

Jenkins, L. N., Floress, M. T., \& Reinke, W. (2015). Rates and types of teacher praise: A review and future directions. Psychology in the Schools, 52(5), 463-476.

https://doi.org/10.1002/pits.21835

Kementerian Pendidikan dan Kebudayaan. (2016). Analisis sumber daya manusia pendidikan dasar dan menengah [Analysis of human resources for primary and secondary education]. http://publikasi.data.kemdikbud.go.id/uploadDir/isi_C3E61ED4-94A4-4C8E-AFEE091C89F6BF53_.pdf

Kırkgöz, Y., \& Ağçam, R. (2012). Investigating the written assessment practices of Turkish Teachers of English at primary education. The Journal of Language and Linguistic Studies, 8(2), 119-136. http://www.jlls.org/vol8no2/119-136.pdf

Košir, K., \& Tement, S. (2014). Teacher-student relationship and academic achievement: a cross-lagged longitudinal study on three different age groups. European Journal of Psychology of Education, 29(3), 409-428. https://doi.org/10.1007/s10212-013-0205-2

Krashen, S., \& Mason, B. (2019). A note on comprehension checking. Journal of English Language Teaching , 61(1), 23-32.

Kunter, M., Klusmann, U., Baumert, J., Richter, D., Voss, T., \& Hachfeld, A. (2013). Professional competence of teachers: Effects on instructional quality and student development. Journal of Educational Psychology, 105(3), 805-820. https://doi.org/10.1037/a0032583

Kurniawan, B. D. (2011). Implementasi kebijakan sertifikasi guru dalam rangka meningkatkan profesionalitas guru di Kota Yogyakarta [Implementation of teacher certification policies to improve teacher professionalism in Yogyakarta]. Jurnal Studi Pemerintahan, 2(2), 278299. https://doi.org/10.18196/jgp.2011.0015

Kusumawardhani, P. N. (2017). Does teacher certification program lead to better quality teachers? Evidence from Indonesia. Education Economics, 25(6), 590-618. https://doi.org/10.1080/09645292.2017.1329405

Lie, A., Tamah, S. M., Trianawaty, T., Triwidayati, K. R., \& Jemadi, F. (2019). English proficiency of secondary school teachers in Indonesia. Beyond Words, 7(2), 86-100. https://doi.org/10.33508/bw.v7i2.1950

Lightbown, P. M., \& Spada, N. (2020). Teaching and learning L2 in the classroom: It's about time. Language Teaching, 53(4), 422-432. https://doi.org/10.1017/S0261444819000454

Machali, I. (2013). Kebijakan perubahan kurikulum 2013 dalam menyongsong Indonesia emas tahun 2045 [2013 curriculum change policy in welcoming a golden Indonesia in 2045]. Jurnal Pendidikan Islam, 3(1), 94. https://doi.org/10.14421/jpi.2014.31.71-94

Macwan, H. J. (2015). Using visual aids as authentic material in ESL classrooms. Research Journal of English Language and Literature, 3(1), 91-96. 
Mahler, D., Großschedl, J., \& Harms, U. (2018). Does motivation matter? - The relationship between teachers' self-efficacy and enthusiasm and students' performance. PLOS ONE, 13(11), e0207252. https://doi.org/10.1371/journal.pone.0207252

Mahmudah, D. R. (2013). A comparative study on the English teaching skills between the certified and non-certified English teachers in Bantaeng regency. Exposure, 2(2), 177-188. https://doi.org/10.26618/EXPOSURE.V2I2.789

Martínez-Jiménez, R., \& Ruiz-Jiménez, M. C. (2020). Improving students'satisfaction and learning performance using flipped classroom. International Journal of Management Education, 18(3), 100422. https://doi.org/10.1016/j.ijme.2020.100422

McGrath, I. (2013). Teaching materials and the roles of EFL/ESL teachers: Practice and theory. Bloomsbury.

McKenzie, K., Murray, K. R., Murray, A. L., \& Richelieu, M. (2015). The effectiveness of university counselling for students with academic issues. Counselling and Psychotherapy Research, 15(4), 284-288. https://doi.org/10.1002/capr.12034

Munfangati, R., \& Widodo, P. (2014). Kinerja guru bahasa Inggris bersertifikat pendidik di kota Yogyakarta [The performance of certified English teachers in the city of Yogyakarta]. LingTera, 1(2), 236. https://doi.org/10.21831/lt.v1i2.2598

Namaziandost, E., \& Imani, A. (2020). Compensatory strategies and Iranian intermediate EFL learners' speaking fluency: Focusing on self-repetition and comprehension check strategies the impacts of spaced and massed distribution instruction on EFL learners' vocabulary learning view project. International Journal of Linguistics, Literature and Translation, 3(3), 107-114. https://doi.org/10.32996/ijllt.2020.3.3.11

Nation, P., \& Macalister, J. (2019). Language curriculum design (2nd ed.). Routledge.

Nawaz, N., \& Yasin, H. (2015). Determinants of motivation in teachers: A study of private secondary schools chain networks in Bahawalpur. Journal of Education and Practice, 6(4), $55-59$.

Odukoya, J. A., Adekeye, O., Igbinoba, A. O., \& Afolabi, A. (2018). Item analysis of universitywide multiple choice objective examinations: the experience of a Nigerian private university. Quality \& Quantity, 52(3), 983-997. https://doi.org/10.1007/s11135-017-0499-2

Pailthorpe, B. C. (2017). Emergent Design. In The International Encyclopedia of Communication Research Methods (pp. 1-2). https://doi.org/10.1002/9781118901731.iecrm0081

Park, I. (2005). Teacher commitment and its effects on student achievement in American high schools. Educational Research and Evaluation, 11(5), 461-485. https://doi.org/10.1080/13803610500146269

Payne, M. W., \& Contreras, J. P. (2019). Ecuadorian students' perception on the use of translation in the EFL classroom. Studies in English Language and Education, 6(1), 61-70. http://www.jurnal.unsyiah.ac.id/SiELE/article/view/12072

Rahimi, M., \& Karkami, F. H. (2015). The role of teachers' classroom discipline in their teaching effectiveness and students' language learning motivation and achievement: A path 
method. Iranian Journal of Language Teaching Research, 3(1), 57-82.

Ramli, R. (2014). Implementation and impact of teacher certification program in Indonesia (Perspective in education). Jurnal Bahasa Lingua Scientia, 6(2), 227-233. https://doi.org/10.21274/1s.2014.6.2.227-233

Reddington, E. (2015). Humor and play in language classroom interaction: A review of the literature. Studies in Applied Linguistics and TESOL, 15(2), 22-38. https://doi.org/10.7916/SALT.V15I2.1271

Rindarti, E. (2018). Peningkatan kompetensi guru dalam mengembangkan RPP kurikulum 2013 revisi 2017 melalui pendampingan berkelanjutan [Increasing teacher competence in developing the 2017 revised 2013 curriculum lesson plan through continuous mentoring]. Jurnal Pendidikan Islam, 9(1), 59-74.

Ripollés, P., Marco-Pallarés, J., Hielscher, U., Mestres-Missé, A., Tempelmann, C., Heinze, H. J., Rodríguez-Fornells, A., \& Noesselt, T. (2014). The role of reward in word learning and its implications for language acquisition. Current Biology, 24(21), 2606-2611. https://doi.org/10.1016/j.cub.2014.09.044

Shalem, Y., Steinberg, C., Koornhof, H., \& De Clercq, F. (2017). The what and how in scripted lesson plans: the case of the Gauteng Primary Language and Mathematics Strategy. Journal of Education, 66, 13-36. https://doi.org/10.17159/2520-9868/i66a01

Shapira-Lishchinsky, O. (2011). Teachers' critical incidents: Ethical dilemmas in teaching practice. Teaching and Teacher Education, 27(3), 648-656. https://doi.org/10.1016/j.tate.2010.11.003

Siswandari, S., \& Susilaningsih, S. (2013). Dampak sertifikasi guru terhadap peningkatan kualitas pembelajaran peserta didik. Jurnal Pendidikan Dan Kebudayaan, 19(4), 478-498. https://doi.org/10.24832/jpnk.v19i4.305

Skipper, Y., \& Douglas, K. (2012). Is no praise good praise? Effects of positive feedback on children's and university students' responses to subsequent failures. British Journal of Educational Psychology, 82(2), 327-339. https://doi.org/10.1111/j.2044-8279.2011.02028.x

Sointu, E. T., Savolainen, H., Lappalainen, K., \& Lambert, M. C. (2017). Longitudinal associations of student-teacher relationships and behavioural and emotional strengths on academic achievement. Educational Psychology, 37(4), 457-467. https://doi.org/10.1080/01443410.2016.1165796

Sougari, A.-M. (2011). Student teachers' decision-making skills in relation to lesson planning: The impact of a practicum. Selected Papers on Theoretical and Applied Linguistics, 19, 403-412. https://doi.org/10.26262/istal.v19i0.5518

Stanger-Hall, K. F. (2012). Multiple-choice exams: An obstacle for higher-level thinking in introductory science classes. CBE-Life Sciences Education, 11(3), 294-306. https://doi.org/10.1187/cbe.11-11-0100

Steinmayr, R., Weidinger, A. F., \& Wigfield, A. (2018). Does students' grit predict their school achievement above and beyond their personality, motivation, and engagement?

Contemporary Educational Psychology, 53, 106-122. https://doi.org/10.1016/j.cedpsych.2018.02.004 
Sudja, I. N., \& Yuesti, A. (2017). The influences of education and training, leadership, work environment, teacher certification on discipline and teacher's professionality In high school at Bali province. Scientific Research Journal, 5(9), 102-108.

Suharjati, F. (2010). History of teaching English as a foreign language in Indonesia. DEIKSIS, 2(03), 161-168. https://doi.org/10.30998/DEIKSIS.V2I03.401

Suprihatiningrum, J. (2014). Guru profesional: Pedoman kinerja, kualifikasi, \& kompetensi guru [Professional teachers: Teacher performance, qualification \& competency guidelines]. Yogjakarta: Ar-Ruzz Media.

Suratman, B., Wulandari, S. S., Nugraha, J., \& Narmaditya, S. (2020). Does teacher certification promote work motivation and teacher performance? A lesson from Indonesia. International Journal of Innovation, Creativity and Change, 11(10), 516-525.

Taniredja, T., \& Abduh, M. (2016). Pedagogical, personality, social and professional competence in correlation with teachers' performance (Correlational study of junior high school teacher at SMPN 3 Purwokerto). The 2nd International Conference on Science, Technology, and Humanity, 264-272.

Tok, H. (2010). TEFL textbook evaluation: From teachers' perspectives. Educational Research and Reviews, 5(9), 508-517. https://doi.org/10.5897/ERR.9000329

Tran, Y. (2015). ESL pedagogy and certification: Teacher perceptions and efficacy. Journal of Education and Learning, 4(2), 28-42. https://doi.org/10.5539/jel.v4n2p28

Triwiyanto, T. (2013). Standar nasional pendidikan sebagai indikator mutu layanan manajemen sekolah [National education standards as an indicator of the quality of school management services]. Jurnal Ilmu Pendidikan, 19(2), 161-171. https://doi.org/10.17977/JIP.V19I2.4208

Vygotsky, L. S. (1964). Thought and language. Bulletin of the Orton Society, 14(1), 97-98. https://doi.org/10.1007/BF02928399

Wardoyo, C. (2015). The measurement of teacher's personality competence and performance using embedded model. Journal of Education and Practice, 6(26), 18-23.

Watanabe, Y., \& Swain, M. (2008). Perception of learner proficiency: Its impact on the interaction between an ESL learner and her higher and lower proficiency partners. Language Awareness, 17(2), 115-130. https://doi.org/10.1080/09658410802146651

Weber, H. S., Lu, L., Shi, J., \& Spinath, F. M. (2013). The roles of cognitive and motivational predictors in explaining school achievement in elementary school. Learning and Individual Differences, 25, 85-92. https://doi.org/10.1016/j.lindif.2013.03.008

Wen-Cheng, W., Chien-Hung, L., \& Chung-Chieh, L. (2011). Thinking of the textbook in the ESL/EFL classroom. English Language Teaching, 4(2), 91. https://doi.org/10.5539/elt.v4n2p91

Wigfield, A., Tonks, S. M., \& Klauda, S. L. (2016). Expectancy-Value Theory. In Handbook of motivation at school. Routledge. https://doi.org/10.4324/9781315773384.ch4

Wiseman, A. W., \& Al-bakr, F. (2013). The elusiveness of teacher quality: A comparative analysis of teacher certification and student achievement in Gulf Cooperation Council (GCC) countries. Prospects, 43(3), 289-309. https://doi.org/10.1007/s11125-013-9272-z 
Zaidi, N. L. B., Grob, K. L., Monrad, S. M., Kurtz, J. B., Tai, A., Ahmed, A. Z., Gruppen, L. D., \& Santen, S. A. (2018). Pushing critical thinking skills with multiple-choice questions: Does Bloom's taxonomy work? Academic Medicine, 93(6), 856-859. https://doi.org/10.1097/ACM.0000000000002087

Zaim, M. (2012). Perbandingan kinerja guru Bahasa Inggris SMA Kota Padang Panjang yang belum dan telah sertifikasi dilihat dari kompetensi pedagogik dan profesional [The comparison of pedagogical and professional competences of certified and non-certified English teachers at SMA Padang Panjang]. International Conference on Languages and Arts, 0(0), 281-295. http://ejournal.unp.ac.id/index.php/isla/article/view/3985

Ziyaeemehr, A., Kumar, V., \& Abdullah, M. (2011). Use and non-use of humor in academic ESL classrooms. English Language Teaching, 4(3), 111-119.

https://doi.org/10.5539/elt.v4n3p111

Zulfikar, Z. (2016). Benefits of web-based or electronic portfolio assessment in ESL classroom. Englisia: Journal of Language, Education, and Humanities, 4(1), 1-9. https://doi.org/10.22373/ej.v4i1.752

Zulfikar, Z. (2019). Rethinking the use of L1 in L2 classroom. Englisia: Journal of Language, Education, and Humanities, 6(1), 43-51. https://doi.org/10.22373/ej.v6i1.2514

Zulfikar, Z., \& Aulia, C. T. (2020). Exploring Acehnese EFL college students' perceptions on collaborative writing. Wanastra : Jurnal Bahasa Dan Sastra, 12(2), 171-180. https://doi.org/10.31294/w.v12i1 